\title{
Žemaičių Naumiesčio seniūnijos kraštovaizdžio geografinè-retrospektyvinẻ analizė
}

\author{
Angelija Bučienè ${ }^{1}$, \\ Sébastien Gadal², \\ Jelena Galiniené ${ }^{1}$, \\ Viktoras Gailius ${ }^{1}$ \\ ${ }^{1}$ Klaipedos universitetas, \\ Herkaus Manto g. 84, \\ LT-92294 Klaipèda \\ El.paštas: angelijab@gmail.com; \\ elenasynanovic@gmail.com; \\ viktorasgailius@gmail.com \\ ${ }^{2}$ Aix-Marseille Univ, \\ CNRS, ESPACE UMR 7300, \\ Univ Nice Sophia Antipolis, \\ Avignon Univ, Prancūzija \\ El.paštas sebastien.gadal@univ-amu.fr
}

Bučienė A., Gadal S., Galinienė J., Gailius V. Žemaičiu Naumiesčio seniūnijos kraštovaizdžio geografinè-retrospektyvinè analizè. Geologija. Geografija. 2017. T. 3(1). ISSN 2351-7549.

Tyrimui pasirinkta dabartinè Žemaičių Naumiesčio seniūnijos užimama teritorija ir jos kraštovaizdžio komponentai, apžvelgiamas pastarụjų 25-30 metų laikotarpis. Nagrinëjami santykinai natūralūs ir agrariniai-urbanistiniai kraštovaizdžio komponentai, taip pat socialiniai-demografiniai kraštovaizdžio pokyčius lemiantys veiksniai bei jų kaita bègant laikui ir erdvèje siekiant išskirti bendriausias kaitos tendencijas. Darbe naudoti statistinès, istorinių dokumentų analizės, nuotoliniai ir GIS modeliavimo metodai. Tyrimas atskleidè, kad antroje sovietmečio puseje tiriamoje teritorijoje vyravo agrarinis mažai urbanizuotas kraštovaizdis. XXI a. pradžioje agrarinių ir urbanizuotų (užstatytų) teritorijų sumažèjo, santykinai natūralių žemèveikslių (vandenų) plotas liko nepakitęs arba šiek tiek padidèjo (miškų), tačiau sumažèjo kaimo gyventojų skaičius, o trims kaimams gresia išnykimas.

Raktažodžiai: Žemaičių Naumiestis, kraštovaizdžio komponentai, kaitos analizé, nuotoliniai metodai, geografinis-retrospektyvinis požiūris

\section{IVADAS}

Mažų miestelių sąvoka ịvairiose šalyse apibrèžiama gana skirtingai. Šiaurès šalių, pavyzdžiui, Švedijos, oficialioje statistikoje miestais ir miesteliais laikomos tos gyvenamosios vietovès, kuriose ịsikūrę iki 10000 žmonių, o mažomis gyvenamosiomis vietovėmis laikomos turinčios nuo 150 iki 199 gyventojų, kai jų namai nutolę ne daugiau kaip $150 \mathrm{~m}$ vienas nuo kito (Tätorter..., 2012; Småorter..., 2010). Anglai neturi išskyrę mažo miestelio termino, bet pati miesto sąvoka įvairuoja priklausomai nuo gyvenamosios aplinkos užstatymo kompaktiškumo bei ją supančios erdvès tankumo (Urban and Rural..., 2013). Prancūzijoje mažais miesteliais laikomi tie, kuriuose gyvena nuo 1500 iki 10000 žmonių (Great small towns..., 2010-2016),
Vokietijoje (Kleinstadt - vok. k.) - nuo 5000 iki 20000 gyventojų (Kleine und mittlere..., 2004). Europoje mažais ir vidutiniais miestais pagal tyrimų projektą TOWN - Small and medium sized towns in their functional territorial context (ESPON programa) laikomi miestai, turintys nuo $5000 \mathrm{iki}$ 50000 gyventojų (Challenges of small..., 2015). LR teritorijos administracinių vienetu ir jų ribų istatyme nurodoma, kad miesteliai yra kompaktiškai užstatytos gyvenamosios vietovès, turinčios nuo 500 iki 3000 gyventojų, kurių dauguma dirba pramoneje, verslo bei gamybinès ir socialinès infrastruktūros srityse, taip pat tradiciniai miesteliai (Lietuvos Respublikos..., 1994). Remiantis $2011 \mathrm{~m}$. gyventojų surašymo duomenimis, Lietuvoje buvo 249 miesteliai (Gyventojų skaičiaus..., 2013), iš juc Šilutès rajone - 7: tai Gardamas, Katyčiai, Kintai, 
Rusnè, Švèkšna, Vainutas ir Žemaičių Naumiestis. Žemaičių Naumiestis, įsikūręs prie Šusties ir jo intako Šelmens santakos, yra seniūnijos centras. Seniūniją sudaro 9 seniūnaitijos su 33 kaimais (1 pav.).

Mažųjų istorinių miestų gyventojus apjungia identitetas. Vien ekonominio naudingumo kriterijais pagrịsta miestelių plètra formuoja miestelį, prarandantị savo individualius bruožus. Jei yra išsaugotos miestelių ar kaimų tradicijos ir kultūra, tačiau trūksta naujos veiklos, jie stagnuoja. Labai svarbu sukurti tokią situaciją, kuri būtų palanki plètoti miestelio daugiafunkciškumą, efektyviai panaudoti per amžius sukurtą gamtos bei istorini paveldą (Bučas, 1988). Šio tyrimo tikslas - išnagrinèti dabartinès Žemaičių Naumiesčio seniūnijos santykinai natūralius ir agrarinius-urbanistinius kraštovaizdžio komponentus, taip pat socialiniusdemografinius veiksnius bei jų kaitą bėgant laikui (nuo sovietmečio iki šių dienų) ir erdveje, išskiriant bendriausias kaitos tendencijas, kurias būtų galima pritaikyti planuojant kitų mažų Lietuvos miestelių ir seniūnijų teritorijas ir formuojant kultūrinị kraštovaizdị.

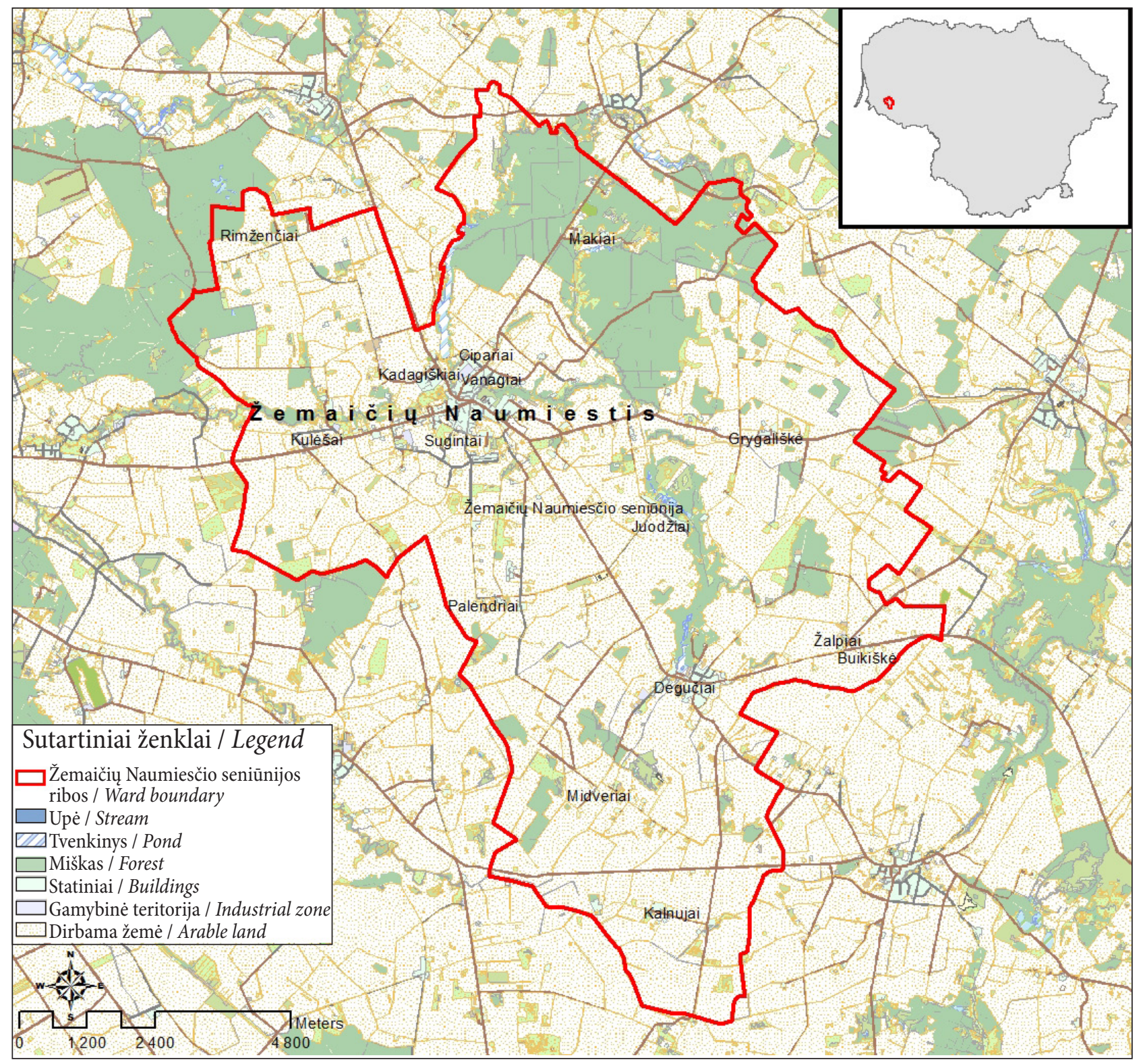

1 pav. Žemaičių Naumiesčio seniūnija su pagrindiniais kaimais ir Žemaičiu Naumiesčio miesteliu

Fig. 1. The Žemaičiu Naumiestis ward with the main villages and Žemaičiu Naumiestis town

Šaltinis / Sources: Lietuvos Respublikos teritorijos M 1:10 000 georeferencinio pagrindo duomenų bazė GDB10LT. Nacionalinè žèmès tarnyba prie Žèmès ūkio ministerijos. Sudaryta naudojantis ArcMap 10.4.1 programine įranga, 2017. 


\section{METODAI}

Visos savivaldybès Lietuvoje taikant OECD metodiką, kuri teritorijos kaimiškumą ìvertina pagal kaimo gyventojų procentą, bendrą gyventojų tankumą ir savivaldybès centro atstumą nuo didelių miestų, buvo suskirstytos ị tris grupes: 1) kaimiškąsias; 2) iš dalies kaimiškąsias ir 3) miesto (Melnikienè, Vidickienè, 2010). Šilutès rajono savivaldybè pateko tarp kaimiškujų savivaldybių. Tyrimui pasirinkta dabartinè Žemaičių Naumiesčio seniūnijos užimama teritorija, kurios plotas $2016-2017 \mathrm{~m}$. sieke $111,4 \mathrm{~km}^{2}$. Jos kraštovaizdis, pagal prof. A. Basalyką, patenka i moreninių lygumų žemėvaizdžio regioną, kuriame taip pat atsispindi ir upių slènių žemévaizdis (Basalykas, 1977). Prof. P. Kavaliausko (2011) tvirtinimu, ši vietové priskiriama dviejų kraštovaizdžio rajonų sandūrai - Nemuno žemupio miškingos ir Vakarų Žemaičiu pietinès miškingos agrarinès lygumos rajonams. Tad Žemaičių Naumiesčio apylinkèse sutinkami molingų ir smèlingų lygumų, banguoto ir slenniuoto agrarinio mažai urbanizuoto kraštovaizdžio fiziomorfotopai.

Darbe nagrinejjami santykinai natūralūs (miškai, vandenys) ir agrariniai-urbanistiniai (žemès ūkio naudmenos, iš jų ariama žemé, pievos ir ganyklos, užstatytos teritorijos) kraštovaizdžio komponentai ir jų plotai, taip pat socialiniai-demografiniai kraštovaizdžio pokyčius lemiantys veiksniai (gyventojų skaičius, tankumas, kaimų dydis) bei kaita. Darbe naudoti kartografiniai, statistinès, istorinių dokumentų analizès, nuotoliniai ir GIS erdvinès analizès modeliavimo metodai. Iš nuotolinių metodų taikytas palydovinių nuotraukų (Landsat 4 TM 1988 m., Landsat 5 TM 1998 ir $2005 \mathrm{~m}$. ir Landsat 8 OLI 2015 m.) ir ortografinių nuotraukų (1997 ir 2013 m.) metodai. Palydovinių nuotraukų metodu buvo suskaitmeninti geografiniai teritoriniai landšaftų žeménaudos (miškų, žemès ūkio naudmenų, užstatytų teritorijų) plotų pokyčiai $297 \mathrm{~km}^{2}(16,5 \times 18 \mathrm{~km})$ tirtame Žemaičių Naumiesčio seniūnijos areale. Landsat serijos nuotraukos, darytos vasaros metu, buvo gautos iš USGS (United States Geological Survey - JAV geologinès tarnybos). Kraštovaizdžio komponentų kaita analizuota išlaikant multispektrinę erdvinę $900 \mathrm{~m}^{2}(30 \times 30 \mathrm{~m})$ rezoliuciją. Atskirų kraštovaizdžio komponentų ekstrakcija atlikta naudojantis Sobed Edge Detectors (SED).

Darbe buvo lygintos GIS 1997 ir $2013 \mathrm{~m}$. duomenų bazès. Šio metodo taikymo metu nau- dota $2013 \mathrm{~m}$. Lietuvos Respublikos teritorijos M 1:10 000 georeferencinio pagrindo duomenų bazė GDB10LT, priklausanti Nacionalinei žemès tarnybai prie Žemès ūkio ministerijos.

Sukèlus 2013 m. duomenų miško sluoksnio bazę i ArcMap 10.4.1 programinę įrangą, atliktas duomenų bazių geometrinis koregavimas pagal 1997 ir $2013 \mathrm{~m}$. ortografinius žemèlapius. Remiantis šiomis duomenų bazèmis bei ortografinėmis nuotraukomis, vykdytos tiriamosios teritorijos mišku plotų korekcijos dabartinèje Žemaičių Naumiesčio seniūnijoje. Tyrimo metu naudotas 1997 ir $2010 \mathrm{~m}$. Lietuvos skaitmeninis ortografinis M 1:10 000 žemèlapis ORT10LT, kuris pasitelktas georeferencinio pagrindo GDB10LT geometriniam koregavimui. Suskaitmeninus palydovines nuotraukas, pakoregavus georeferencines duomenų bazes bei jas derinant su ortografinemis nuotraukomis, gautos labiau pagrịstos išvados apie kraštovaizdžio komponentų kaitos tendencijas.

\section{TYRIMŲ REZULTATAI}

\section{Trumpa miestelio ir jo apylinkių apgyvendinimo} ir administravimo istorija

Pavieniai akmeniniai titnago dirbiniai, esantys Žemaičių Naumiesčio muziejuje, rasti Budrikuose, Gardame, Girininkuose, leidžia teigti, kad naujajame akmens amžiuje (2200-1800 m. pr. Kr.) miestelio apylinkèse jau gyveno žmonès, susibūrę ì bendruomenes ir dažniausiai apsistoję prie upių irengtose stovyklavietėse. XVI a. Naumiestis (Nowe Miasto - lenku k.) ir jo apylinkès tapo Lietuvos ir Lenkijos karalių valstybiniu dvaru. Naumiestis - tai senasis miestelio vardas, kuris buvo išlikęs ir po paskutinio Lenkijos-Lietuvos padalijimo. Valdant Rusijos imperijai, nuo $1881 \mathrm{~m}$. miestelis vadintas Aleksandrovsku. Po 1863-1864 m. sukilimo, uždraudus lietuvišką spaudą, miestelis tapo svarbiu draudžiamos literatūros platinimo punktu: per ji èjo vienas iš svarbiausių knygnešių kelių. Žemaičių Naumiesčio oficialus vardas miesteliui suteiktas tik XX a. ketvirtajame dešimtmetyje (Žemaičių Naumiestis..., 1984). Dèl patogios geografinès padèties Žemaičių Naumiestis, issikūręs prie pat Mažosios Lietuvos sienos, ilgus amžius buvo turgų ir mugiu vieta. Nuo seno pagrindiniai miestelio gyventoju verslai buvo amatai ir prekyba, kuriais daugiausia versdavosi vietiniai žydai ir vokiečiai. Žydų bendruomené, istorinių šaltinių teigimu, buvo vyraujanti 
miestelyje, nors nuo senų laikų čia gyveno ir nemažai lietuvininkų, t. y. evangelikų liuteronų tikẻjimo lietuvių, daugiausia atsikèlusių iš buvusios Rytų Prūsijos ir Klaipèdos krašto. Daug lietuvininkų gyveno pačiame Žemaičių Naumiestyje, Buikiškès, Sugintų, Pauparių, Palendrių, Midverių, Gardamo, Rimženčių ir kituose kaimuose. Be to, kaip ir visoje Paprūsijoje, čia būta daug stambių ūkių, kur palyginti geromis sąlygomis buvo samdomi sezoniniai darbininkai (Mūsų Lietuva..., 1968).

Per tarpukari (nuo $1919 \mathrm{~m}$. ir vèliau) iki pat antrosios sovietinès okupacijos Naumiesčio valsčius gyvavo Tauragès apskrities sudètyje, o jo plotas buvo tik $228 \mathrm{~km}^{2}$. Nuo 1947 iki $1950 \mathrm{~m}$. jis buvo priskirtas Šilutès apskričiai, turèjo 13 apylinkių (Lietuvos TSR..., 1949). Valsčius panaikintas 1950 m. birželio 20 d., jo teritorija perduota Šilutès rajonui. Žemaičių Naumiestis nuo 1959 m. buvo priskirtas miesto tipo gyvenvietei ir buvo apylinkès centras, sovietinio ūkio centrinè gyvenvietè. Atgavus nepriklausomybę, Žemaičių Naumiestis tapo seniūnijos centru, o nuo $1997 \mathrm{~m}$. gavo miestelio statusą (Žemaičių Naumiestis..., 1984).

Atskirais metais nuo XIX a. vidurio iki XXI a. pradžios keitèsi miestelio plotas ir gyventojų skaičius, o daugiausia gyventoju jame buvo $1985 \mathrm{~m}$. (2 500), nors labai panašus skaičius fiksuotas ir XIX a. pabaigoje (Žemaičių Naumiestis..., 2015).
Žemaičių Naumiesčio apylinkès plotas sovietmečiu kito, nes kai kurie kaimai ar jų dalys būdavo prijungiamos prie kitų apylinkių, bet nuo 1959 m. iki Nepriklausomybès atkūrimo apylinkès plotas buvo apie 15-16 \% mažesnis nei dabartinès Žemaičių Naumiesčio seniūnijos. Gyventojų skaičius apylinkejje / seniūnijoje didejo nuo 1959 iki 1970 m., bet vèliau èmé mažèti, ir ypač sumažèjo $2011 \mathrm{~m}$. (1 lentelè).

Didžiausias apylinkèje / seniūnijoje gyventojų skaičius ir tankumas buvo 1970 m., vèliau abu rodikliai mažèjo ir minimalias reikšmes pasiekè 2011 m. Pastaraisiais 2016-2017 m. gyventoju skaičius seniūnijoje stabilizavosi, tad ir tankumas šiek tiek padidejjo.

\section{Seniūnijos kaimai ir jų gyventojų kaita}

Paprūsèje (maždaug apimančioje Jurbarko ir Tauragès rajonus, Klaipèdos, Šilutès ir Kretingos rajonų dalis) buvo nemažai gatvinių kaimų, išsiskyrusių specifine struktūra. Ten būta ir savitų reguliarių viensẻdinių kaimų (Rytprūsių-Mažosios Lietuvos kaimų analogų). Tai rodo šios pozonès istorinius ryšius su gretimu kraštu, kai kurių gyvensenos bruožų perèmimą. Pavyzdžiui, tarp grupès kaimų pietvakarinèje Žemaitijoje - Paprūsèje (Žemaičių Naumiesčio apylinkès) XX a. pradžioje vienas greta kito gyvavo skirtingų struktūrų kaimai:

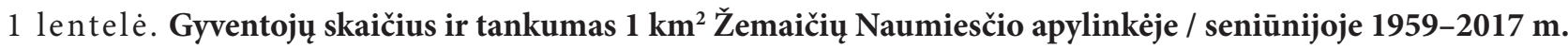
Table 1. Population size and average density per $1 \mathrm{~km}^{2}$ in Žemaičių Naumiestis locality and ward in 1959-2017

\begin{tabular}{c|c|c}
\hline $\begin{array}{c}\text { Metai } \\
\text { Year }\end{array}$ & $\begin{array}{c}\text { Gyventojų skaičius apylinkèje / seniūnijoje } \\
\text { Population in locality/ward }\end{array}$ & $\begin{array}{c}\text { Tankumas apylinkèje / seniūnijoje } \mathbf{1} \mathbf{k m}^{\mathbf{2}} \\
\text { Density in locality/ward per } \mathbf{1} \mathbf{~ k m}^{\mathbf{2}}\end{array}$ \\
\hline 1959 & 4408 & 45,7 \\
\hline 1970 & 4744 & 49,2 \\
\hline 1979 & 4615 & 47,9 \\
\hline 1989 & 4081 & 42,3 \\
\hline 2001 & 3916 & 35,2 \\
\hline 2011 & 3281 & 29,4 \\
\hline 2016 & 3388 & 30,4 \\
\hline 2017 & 3312 & 29,7 \\
\hline
\end{tabular}

Paaiškinimas: tankumas apskaičiuotas naudojant seniūnijos $\left(111,4 \mathrm{~km}^{2}\right)$ ir apylinkès $\left(96,4 \mathrm{~km}^{2}\right)$ plotą.

Explanation: density estimated using $111.4 \mathrm{~km}^{2}$ as ward area, and $96.4 \mathrm{~km}^{2}$ as locality area.

Šaltiniai / Sources: (Lietuvos TSR kaimo..., 1974; Lietuvos TSR kaimo..., 1982; Kaimo gyvenamosios..., 1993; Žemaičių Naumiestis..., 2015; Klaipėdos apskrities..., 2003; https://www.silute.lt/go.php/Geografiniai-ir-demografiniaiduomenys-792859; Gyventojų skaičiaus..., 2013; seniūnijos duomenys). 
gatviniai-juostiniai Juodžių ir Šeputaičių kaimai; kompaktiška Žalpių gyvenvietė; viensèdiniai Grygališkių, Šiaudvyčių, Kaitininkų kaimai. Struktūrų ivvairovė liudija apie laipsnišką ir netolygų šios teritorijos apgyvendinimą XV-XIX a., skirtingą atskirų gyvenviečių statusą (Purvinas, 2005).
Kadangi nuo sovietmečio iki 2016 m. mažèjo Žemaičiu Naumiesčio apylinkèse ir dabartinejje seniūnijoje gyventojų skaičius (žiūrèti. 1 lentelę), buvo įdomu ištirti (2 pav., 2 lentelè), kokie kaimai ir kurioje seniūnijos dalyje sumažejo labiausiai, o kurie galbūt išaugo.

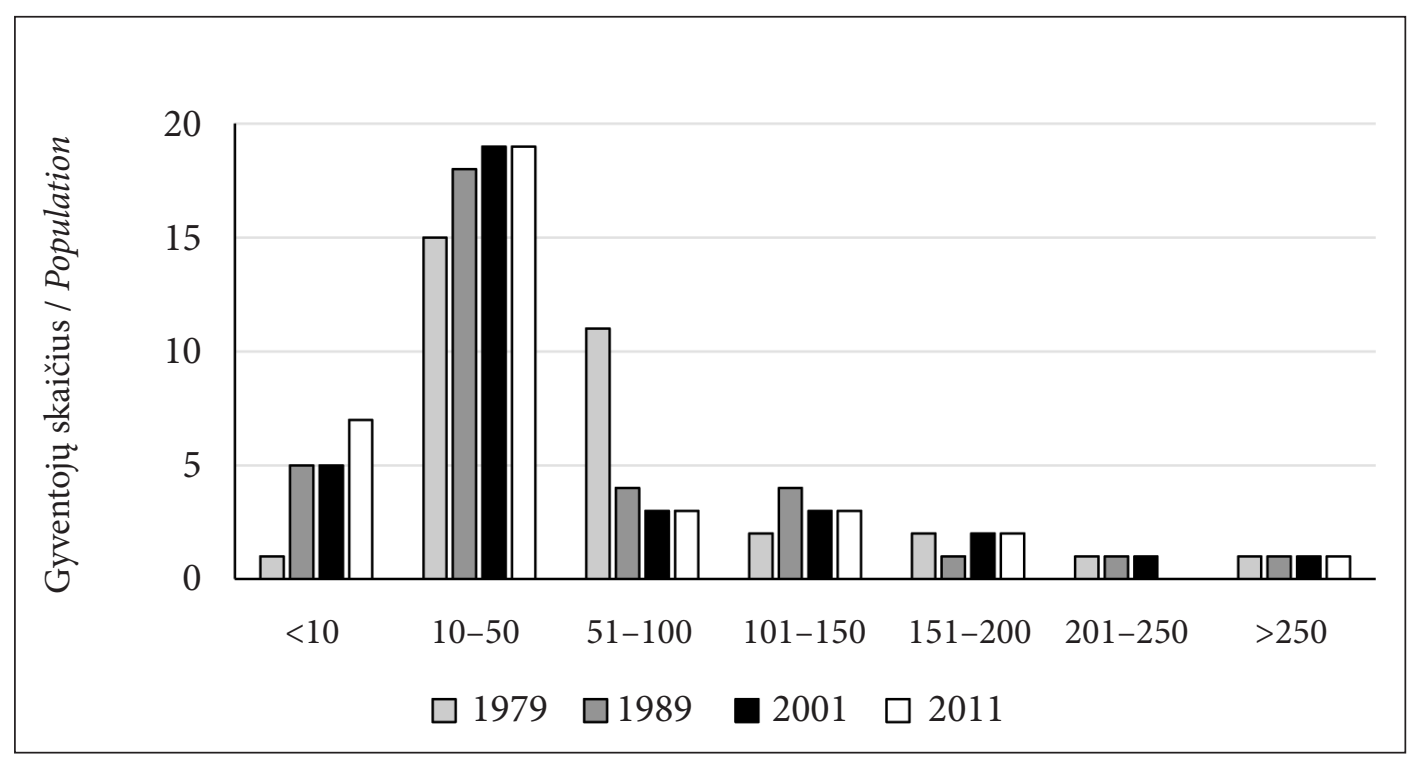

2 pav. Žemaičių Naumiesčio seniūnijos kaimų pasiskirstymas pagal dydị (gyventojų skaičių) 1979, 1989, 2001 ir $2011 \mathrm{~m}$.

Fig. 2. Distribution of villages of Žemaičiu Naumiestis ward according to the size (population) in 1979, 1989, 2001 and 2011

Šaltiniai / Sources: (Lietuvos TSR..., 1949; Lietuvos TSR..., 1959; Lietuvos TSR..., 1974; Lietuvos TSR..., 1984; Klaipėdos apskrities..., 2003; Gyventojų skaičiaus..., 2013)

2 lentelè. Žemaičių Naumiesčio seniūnijos kaimų skaičiaus ir gyventojų pokyčiai nuo 1989 iki $2011 \mathrm{~m}$.

Table 2. Changes in the number of villages and rural population of Žemaičiu Naumiestis ward from 1989 to 2011

\begin{tabular}{|c|c|c|}
\hline $\begin{array}{l}\text { Kaimo gyventojų nuo } 1989 \text { iki } 2011 \text { m. } \\
\text { Rural population from } 1989 \text { till } 2011\end{array}$ & $\begin{array}{c}\text { Kaimų skaičius } \\
\text { Number of villages }\end{array}$ & $\begin{array}{r}\text { Kaimai } \\
\text { Villages } \\
\end{array}$ \\
\hline $\begin{array}{c}\text { sumažèjo }<20 \% \\
\text { decreased }\end{array}$ & 8 & $\begin{array}{l}\text { Žiogaičiai, Kalnujai, Budrikai, Degučiai, } \\
\text { Galnè, Rimženčiai, Sugintai, Vanagiai }\end{array}$ \\
\hline $\begin{array}{c}\text { sumažèjo } 21-40 \% \\
\text { decreased }\end{array}$ & 12 & $\begin{array}{l}\text { Grygališkė, Kalininkai, Kulešaiai, Makiai, } \\
\text { Midveriai, Palendriai, Pažalioji, Raugeliai, } \\
\text { Šeputaičiai, Vaitkaičiai, Venckai, Žalpiai }\end{array}$ \\
\hline $\begin{array}{c}\text { sumažejo } 41-60 \% \\
\text { decreased }\end{array}$ & 4 & Juodžiai, Klebonai, Šiaudviečiai, Užšustis \\
\hline $\begin{array}{c}\text { sumažèjo }>60 \% \\
\text { decreased }\end{array}$ & 3 & Paupariai, Laugaliai, Dèkintai \\
\hline $\begin{array}{c}\text { nepasikeite } \\
\text { did not change }\end{array}$ & 1 & Brokoriai \\
\hline $\begin{array}{c}\text { padidèjo }<20 \% \\
\text { increased }\end{array}$ & 4 & Buikiškè, Kadagiškiai, Snukaliai, Spiečiai \\
\hline $\begin{array}{c}\text { padidejo }>20 \% \\
\text { increased }\end{array}$ & 1 & Tūmeliai \\
\hline
\end{tabular}


Dabartiniu metu seniūnijoje yra 33 kaimai. Didžiausi, kaip ir ankstesniais metais, išliko Degučių, Sugintų, Vanagių, Kadagiškių kaimai. Ir anksčiau, ir dabar gausiausia išliko smulkių kaimų su 10-50 gyventojų grupé, nebeliko 201-250 gyventojų turinčių kaimų, padaugèjo pačių mažiausių kaimų $(<10$ gyventojų). Tarp bendrų kaimo gyventojų ir pačių kaimų mažejimo priežasčių yra ir ta, kad Šilutès rajone prastesnis socialinès darnos indeksas, didesnis vyresnio amžiaus žmonių santykinis dydis, palyginti su kitomis Klaipedos apskrities savivaldybėmis (Bučienè, Gedmintienė, 2015). Dèl to visame Šilutès rajone jau $2001 \mathrm{~m}$. net 12 gyvenviečių liko be gyventojų (Šilutès rajono..., 2010), o Žemaičių Naumiesčio seniūnijoje gyvenamosios vietovès nuo $\mathrm{XX}$ a. pabaigos iki pastarojo laikmečio išliko visos, tik sumažèjusios.

Per 22 metus seniūnijoje vidutiniškai sumažèjo $18,5 \%$ kaimų gyventojų: labiausiai pietrytinejje seniūnijos dalyje (40-60 ir daugiau, \%) - Juodžių, Šiaudviečių, Dèkintų, Laugalių kaimuose. Tačiau yra ir teigiamų pokyčių: Brokorių kaimo gyventojų skaičius nepasikeite, o Buikiškių, Kadagiškių, Snukalių, Spiečių ir Tūmelių kaimų gyventojų padaugẻjo. Mažiausi 2011 m. seniūnijoje liko Dèkintų, Užšusčio ir Klebonų kaimai, atitinkamai su 1, 4 ir 6 gyventojais. Palyginus su kitais Lietuvos regionais, Vakarų Lietuvoje kaimo gyventojų skaičius pradejo mažèti vèliausiai, maždaug nuo 2000 metų, o Lietuvai įstojus ị ES kiekvienais metais kaimo gyventojų èmè mažèti po 1-2 \% (Kriaučiūnas, 2013). Seniūnijos duomenimis, $2017 \mathrm{~m}$. pensinio amžiaus gyventojai sudare $17,4 \%$.

\section{Agrariniai-urbanistiniai ir santykinai natūralūs kraštovaizdžio komponentai ir jų kaita}

Žmogus savo veiklomis keičia kraštovaizdi ir tai priklauso ne tik nuo gamtinių, bet ir nuo socialinių ypatybių, technologinių galimybių, reformų, žemès nuosavybès, ekonominès, geopolitinès situacijos ir pan. (Ribokas, Zlatkutè, 2009). 1940 m. sovietinè okupacija sunaikino ị rinką orientuotą prieškarinę Lietuvos žemès ūkio struktūrą, pakeitè žemèvaldą ir pradejo diegti sovietinę žemès ūkio struktūrą. 1941 m. birželi prasidèjo masinis ūkininkų šeimų trèmimas iš Lietuvos. Prasideję̧s Antrasis pasaulinis karas sutrikdè šiuos žemès ūkio pertvarkymus, tačiau 1944 m. II pusèje SSRS vèl okupavus Lietuvą buvo tęsiama 1940-1941 m. priverstinè žemès reforma, atnaujinti trèmimai, o ištuštejusios sodybos su- teikiamos kuriamiems kolhozams (kolūkiams) ir sovhozams (tarybiniams ükiams) bei i juos atvykusiems persikèlèliams. Nuo $1953 \mathrm{~m}$. kolūkių ir tarybinių ūkių gyvenvietèse pradèta gyvenamųjų namų statyba. Stambinant ūkius, daugelis kaimų buvo paskelbti neperspektyviomis gyvenvietemis. Nuo 1967 m., vykdant melioraciją, gyventojus pradèta masiškai keldinti iš vienkiemių. 1966-1980 m. kasmet žemès ūki palikdavo 24 000-25 000 žmonių, apie $75 \%$ jų - darbingi (Svirskis, 2009).

Per sovietmeti Lietuvoje keitèsi žemès ūkio naudmenų plotai: $1948 \mathrm{~m}$. jos užèmé 4286,3 tūkst. ha, arba 65,6 \%, 1975 m. - 3665 tūkst. ha, o 1989 m. sudare 3 522,8 tūkst. ha, arba 53,9\% nuo bendro šalies ploto (Aleknavičius, 2012). Šilutès rajone $1976 \mathrm{~m}$. žemès ùkio naudmenos užèmè 114010 ha, iš jų ariama žemé sudare 48,4 \% (Selskoje..., 1977). $1970 \mathrm{~m}$. Lietuvoje buvo 301 tarybinis ūkis (Čeginskas, 2009), 1986 m. - 282 tarybiniai ūkiai (Lietuvos TSR..., 1988). Šilutès rajone, kuris sovietmečiu buvo $537 \mathrm{~km}^{2}$ didesnis nei dabartiniu metu, $1987 \mathrm{~m}$. buvo vienas kolūkis ir 23 tarybiniai ūkiai (Šilutès rajonas..., 1988). Žemaičių Naumiesčio apylinkẻje sovietmečio pirmoje pusejje buvo vienas kolūkis (1959), o 1972 m., daugiau kaip du kartus išaugus apylinkès plotui, buvo du tarybiniai ūkiai, besispecializuojantys daržovių sèklininkysteje, pieno ir mėsos gamyboje. 1987 m. ūkio subjektų apylinkeje dar padaugèjo (atsirado mokomasis ūkis, girininkija), nors plotas išliko toks pat (Lietuvos TSR..., 1959; Žemès kadastras, 1989).

Atkūrus Lietuvos nepriklausomybę, ịsigaliojo rinkos santykiai, buvo atliktas visiškas žemės grąžinimas (restitucija) ir suformuota daugybè privačių, dažnai mažo ploto, žemès sklypų. Kai kuriuose Lietuvos regionuose esant sudètingai situacijai žemès ūkio veikla tapo nepelninga, o apleistose žemès ūkio naudmenose prasidejo spartūs ir nevaldomi renatūralizacijos procesai (Milius, Ribokas, 2008). Šalyje agrožemėnaudos plotas keitèsi labai dinamiškai: jei 1990 m. žemès ūkio naudmenų buvo 3 513,5 tūkst. ha ir jos sudare 53,9 \% visos teritorijos, $1995 \mathrm{~m}$. plotas sumažejo 0,5 tūkst. ha. Dar daugiau žemès ūkio naudmenų sumažejo vèlesniais metais: iki $2000 \mathrm{~m}$. - 17,8 tūkst. ha, iki 2005 m. - 30,9 tūkst. ha, o 2010 m. jų plotas sumažèjo iki 53,0 \% nuo bendro teritorijos ploto (Pranckietis, Bogušas, 2013). Kaip nuo sovietmečio pabaigos iki dabartinio laikotarpio Žemaičiu Naumiesčio apylinkèse kito agrarinis kraštovaizdis ir jo 
komponentai, liudija 1988 ir 2015 m. palydoviniu nuotrauku analizè (3 pav.) ir statistiniai bei kartografiniai duomenys, parodantys žeméveikslių plotų pokyčius visoje seniūnijoje (3 lentelè).
Tyrimai rodo, kad visoje seniūnijos teritorijoje ir palydoviniu metodu tirtame Žemaičių Naumiesčio seniūnijos areale $\left(297 \mathrm{~km}^{2}\right)$ sumažejo žemès ūkio naudmenų, ypač ariamos žemės plotų. Nors

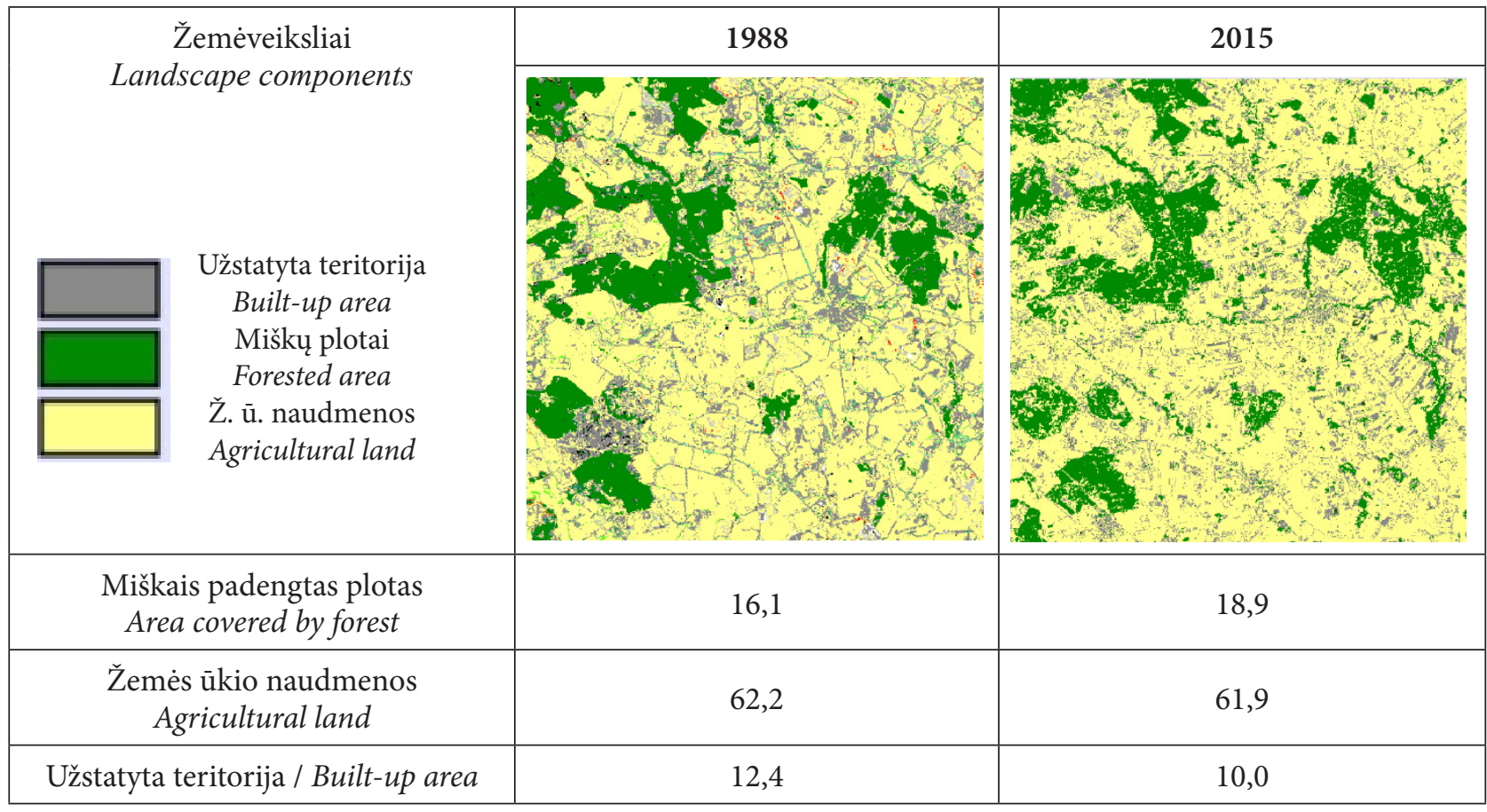

3 pav. Žemėveikslių plotų pokyčiai procentais (visas tirtas plotas $297 \mathrm{~km}^{2}$ ) analizuotame Žemaičių Naumiesčio seniūnijos areale 1988 ir $2015 \mathrm{~m}$. taikant palydovinių nuotraukų metodą

Fig. 3. Changes of landscape component areas in the studied Žemaičiu Naumiestis ward parcel $\left(297 \mathrm{~km}^{2}\right)$ in \% of total area in 1988 and 2015 using satellite images method

3 lentelè. Agrariniai-urbanistiniai ir santykinai natūralūs žemėveiksliai bei jų plotų (\%) nuo bendro ploto kaita Žemaičių Naumiesčio apylinkès ir dabartinès seniūnijos teritorijoje nuo 1985-1988 iki 2010-2015 m. naudojant statistinius-kartografinius duomenis

Table 3. Changes in area of agrarian-urban and relatively natural components of landscape in \% of total area in the territory of Žemaičiu Naumiestis locality and ward from 1985-1988 to 2010-2015 using statistical-cartographic methods

\begin{tabular}{|c|c|c|c|c|c|c|c|}
\hline \multirow{2}{*}{$\begin{array}{l}\text { Metai } \\
\text { Year }\end{array}$} & \multirow{2}{*}{$\begin{array}{c}\text { Bendras } \\
\text { plotas } \\
\text { ha ir \% } \\
\text { Total } \\
\text { area in } \\
\text { ha and \% }\end{array}$} & \multicolumn{3}{|c|}{$\begin{array}{l}\text { Žemės ūkio naudmenos } \\
\text { Agricultural land }\end{array}$} & \multicolumn{2}{|c|}{$\begin{array}{l}\text { Santykinai natūralūs } \\
\text { žemèveiksliai } \\
\text { Relatively natural } \\
\text { landscape components }\end{array}$} & \multirow{2}{*}{$\begin{array}{l}\text { Užstatyta } \\
\text { teritorija } \\
\text { Built-up } \\
\text { territory }\end{array}$} \\
\hline & & $\begin{array}{l}\text { Iš viso } \\
\text { In total }\end{array}$ & $\begin{array}{c}\text { Ariama žemè } \\
\text { Arable land }\end{array}$ & $\begin{array}{l}\text { Pievos ir ganyklos } \\
\text { Meadows and } \\
\text { pastures }\end{array}$ & $\begin{array}{l}\text { Miškai } \\
\text { Forests }\end{array}$ & $\begin{array}{l}\text { Vandenys } \\
\text { Water }\end{array}$ & \\
\hline 1985-1988 & $\begin{array}{c}9640 \\
100\end{array}$ & 72,8 & 50,2 & 22,7 & $\underline{15,0}$ & $\underline{0,5}$ & $\underline{2,3}$ \\
\hline 2010-2015 & $\begin{array}{c}11140 \\
100\end{array}$ & 66,8 & 35,2 & 31,0 & 16,0 & 0,5 & 2,2 \\
\hline
\end{tabular}

Šaltiniai: (http://znaumiestis.puslapiai.lt/index.php?categoryid=11; Žemės kadastras, 1989); seniūnijos duomenys; pabraukti skaičiai apskaičiuoti iš kartografinès medžiagos.

Sources: (http://znaumiestis.puslapiai.lt/index.php?categoryid=11; Žemes kadastras, 1989); data from the ward; underlined figures were estimated using cartographic material. 
kitų žemèveikslių (miškais apaugusių ir užstatytų teritorijų) plotų bendra kaitos tendencija ir buvo analogiška tiek visoje seniūnijos teritorijoje, tiek ir atskirai tirtame Žemaičių Naumiesčio areale, skyrèsi tik kaitos mastai: pastarajame miškų plotų padidèjimas ir užstatytų teritorijų sumažèjimas buvo ryškesnis nei visoje seniūnijos teritorijoje (3 pav., 3 lentelè).

Palydovinių nuotraukų Landsat 5 ir Landsat 8 OLI duomenys atskleidè, kad per pirmuosius aštuonerius nepriklausomybès metus Žemaičių Naumiesčio apylinkèse smulkejjo agrarinių sklypų dydis, t. y. vyko žemès ūkio paskirties plotų fragmentacija, žemès ūkio restruktūrizavimas, lydimas ir pasikeitusių ekonominiu santykių kaime, perèjimo iš centralizuoto / kolektyvinio valdymo ì privatų, reguliuojamą rinkos ekonomikos. Kartu darèsi sudètingesnè kraštovaizdžio mozaika ir visas kompleksas. Vandenų plotai išliko tokie patys tiek seniūnijoje, tiek ir Žemaičių Naumiesčio tirtame areale.

Ortografinių nuotraukų analize taip pat patvirtino, kad per 1997-2013 m. dalis seniūnijos mišku plotų agrariniame kraštovaizdyje šiek tiek padidejo. Labiausiai pagausèjo miškingų plotų ties Juodžiais, Paupariais, Raugeliais, Venckais ir Rimženčiais (4 pav.).

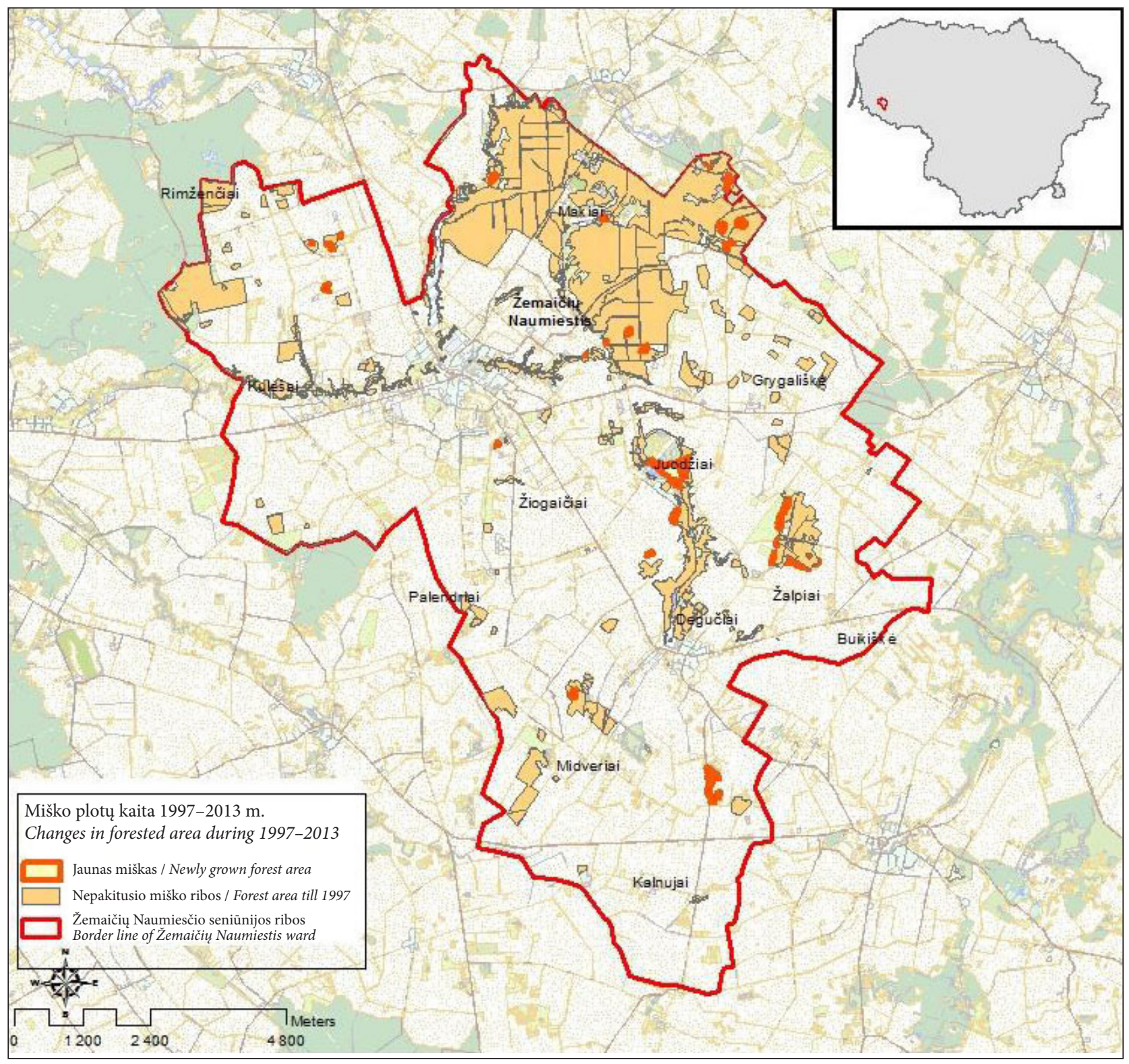

4 pav. Miškingų žemėveikslių pokyčiai 1997-2013 m. pagal ortografines nuotraukas Žemaičių Naumiesčio seniūnijoje Fig. 4. Changes in forested areas in 1997-2013 according to ortographic photo data in Žemaičiu Naumiestis ward 
Analogiška miškingumo kaitos tendencija nuo sovietmečio pabaigos iki pastaruju metu nuotolinių tyrimų duomenimis pastebėta visoje Klaipèdos apskrityje (Gadal, Lekaviciute, 2011).

Nagrinèjant įvairiais nuotoliniais metodais gautus rezultatus pastebèta, kad Šilutès rajone ir Žemaičių Naumiesčio seniūnijoje nuo įstojimo ị ES laikotarpio pradejjo mažèti ūkių skaičius, tad galima daryti prielaidą, kad ūkiai, Lietuvai ịstojus i ES, padidejo, jų sklypai stambejo, o agrarinio kraštovaizdžio fragmentacija stabilizavosi.

Paskutinių dviejų žemès ūkio surašymų duomenys patvirtina nuotoliniais metodais nustatytas kraštovaizdžio agrarinių komponentų plotų kaitos tendencijas (4 lentelè).

Nuo sovietmečio pabaigos agrarinio kraštovaizdžio komponentų Žemaičių Naumiesčio seniūnijoje sumažèjo gerokai mažiau negu visame Šilutès rajone: tą liudija dabar išlikę žemès ūkio naudmenų plotai, kurie rajone vidutiniškai sudaro apie $40 \%$, o seniūnijoje per $66 \%$ nuo bendro ploto.

Per tiriamąji laikotarpi šiek tiek sumažèjo užstatytų teritorijų plotas, taip pat nuo nepriklausomybès pradžios seniūnijoje atsirado nemažai apleistų nenaudojamų pastatų. $2006 \mathrm{~m}$. Vanagių kaime buvo ¡kurtas pirmasis seniūnijoje sertifikuotas mišrus (augalininkystès ir gyvulininkystès) ekologinis ūkis. $2011 \mathrm{~m}$. seniūnijoje registruoti 3 ekologiniai ùkiai, tarp jų du mišrios krypties ir vienas augalininkystès bei vaistažolių auginimo ūkis.

\section{APIBENDRINIMAS IR IŠVADOS}

Tyrimas atskleide, kad antroje sovietmečio pusejje, XX a. aštuntajame-devintajame dešimtme- tyje, tiriamoje teritorijoje vyravo agrarinis mažai urbanizuotas kraštovaizdis. XXI a. pradžioje agrarinių ir urbanizuotų (užstatytų) teritorijų sumažèjo, o santykinai natūralių kraštovaizdžio komponentų (vandenų) plotas liko nepakitęs arba nežymiai padidejo (miškų). Per 22 metus seniūnijoje vidutiniškai sumažèjo 18,5 \% kaimų gyventojų: labiausiai pietrytinèje seniūnijos dalyje (40-60 ir daugiau, \%), kur buvo gausiau mažu kaimų. Trims kaimams - Dèkintų, Užšusčio ir Klebonų - atitinkamai su 1, 4 ir 6 gyventojais šiuo metu gresia išnykimas.

Ivairiais nuotoliniais metodais gauti rezultatai, kaip ir statistiniai duomenys, parode tuos pačius landšafto komponentų plotų pakitimus bėgant laikui, tik pasimatè didesnè sklaidos erdvinè ịvairovè. Sovietmečiu suformuotus stambius agrarinius sklypus žemès reformos pirmoje pusejje pakeitè ryški sklypų fragmentacija, sudètingesnè tapo kraštovaizdžio struktūra ir mozaika. Pastaraisiais metais seniūnijoje stebimas antrinis agrariniu sklypu stambejjimas (konsolidacija) ir agrarinio kraštovaizdžio fragmentacijos stabilizavimas.

Nepaisant įvairių žemèveikslių pokyčių, gyventojų skaičiaus ir kaimų dydžio mažejimo, Žemaičių Naumiesčio seniūnijos kraštovaizdis išliko agrariškesnis nei vidutiniškai Šilutès rajone. Pastaruoju metu agrariné veikla ịvairèja, atsirado ekologinių ūkių, nors ir nežymiai, bet didejja miškingumas. Tad sąlygos atsigauti natūralioms kraštovaizdžio vertybėms seniūnijoje gerèja. Tačiau išlieka būtinybè stiprinti socialinį, ekonominị ir kultūrinị teritorijos statusą, kad stabilizuotųsi gyventojų skaičius, pagerètų amžiaus struktūra ir užimtumas.

4 lentelè. Žemès ūkio naudmenų bei ūkių skaičiaus pokyčiai Šilutės rajone ir Žemaičių Naumiesčio seniūnijoje pagal dviejų paskutinių surašymų duomenis

Table 4. Changes of agricultural land area and farm number in Šilutė district municipality and Žemaičių Naumiestis ward according to the last two Censuses

\begin{tabular}{c|c|c|c|c}
\hline \multirow{2}{*}{$\begin{array}{c}\text { Metai } \\
\text { Year }\end{array}$} & \multicolumn{2}{|c|}{$\begin{array}{c}\text { Ukkių skaičius } \\
\text { Farm number }\end{array}$} & \multicolumn{2}{c}{$\begin{array}{c}\text { Naudojamos žemès ūkio naudmenos ha } \\
\text { Utilised agricultural land, } \text { ha }\end{array}$} \\
\cline { 2 - 5 } & $\begin{array}{c}\text { Rajone } \\
\text { In the district }\end{array}$ & $\begin{array}{c}\text { Seniūnijoje } \\
\text { In the ward }\end{array}$ & $\begin{array}{c}\text { Rajone } \\
\text { In the district }\end{array}$ & $\begin{array}{c}\text { Seniūnijoje } \\
\text { In the ward }\end{array}$ \\
\hline 2003 & 7345 & 829 & 61250 & 6108 \\
\hline 2010 & 6256 & 660 & 68270 & 6654 \\
\hline $\begin{array}{c}\text { Pokytis } \pm \\
\text { Change }\end{array}$ & -1089 & -169 & +7020 & +546 \\
\hline
\end{tabular}

Pastaba: sudaryta remiantis Statistikos departamento duomenimis: www.stat.org.lt

Note: Prepared using the data of the Department of Statistics: $w$ ww.stat.org.lt 


\section{PADE்KA}

Autoriai dèkoja Žemaičių Naumiesčio seniūnijos kolektyvui už geranoriškumą suteikiant įvairią, ypač naujausią, informaciją apie miestelị, seniūnijos kaimus ir jų gyventojus.

Gauta 20170206 Priimta 20170418

\section{Literatūra}

1. Aleknavičius P. 2012. Kaimiškujų teritorijų tvarkymo reguliavimas. Darnaus vystymosi strategija ir praktika. 111-122. https://www. mruni.eu/upload/iblock/713/009_aleknavicius.pdf (žiūrèta 201607 13).

2. Basalykas A. 1977. Lietuvos TSR kraštovaizdis. Vilnius. $239 \mathrm{p}$.

3. Bikelis V. 1959. Lietuvos TSR administracinisteritorinis suskirstymas $1959 \mathrm{~m}$. vasario 1 dienai. Vilnius. $443 \mathrm{p}$.

4. Bučas J. 1988. Lietuvos kaimo kraštovaizdžio raida ir istorines vertybes. Vilnius: Mokslas.

5. Bučienè A., Gedmintienè I. 2015. Research on the problems of sustainable development of rural territories of Klaipeda region: cases of Šilute district and Rusnè ward. Regional Formation and Development Studies. 17(3): 27-39.

6. Challenges of Small and Medium-Sized Urban Areas (SMUAs), Their Economic Growth Potential and Impact on Territorial Development in the European Union and Latvia. 2015. Research report to support the Latvian EU Presidency 2015, Social, Economic and Humanities Research Institute (HESPI) of Vidzeme University of Applied Sciences http://www.dgterritorio.pt/ static/repository/2015-07/2015-07-02160158_ ec7b8803-b0f2-4404-b003-8fb407da00 ca \$ \$DD 45 AEBE- 810 E- 4D A D - 9FB 4 80313412AED7\$\$075BBB7E-72DE-428FAEA7-C0868BD7499F\$\$file_src\$\$pt\$1.pdf (žiūrèta 20160707 ).

7. Čeginskas V. V. 2009. Žemè - tautos gyvybingumo šaltinis. XXI amžius. http://www.xxiamzius.lt/numeriai/2009/07/10/poz_01.html (žiūrèta 201607 15).

8. Gadal S., Lekavičiūtė J. 2011. Remote sensing processing consequences of political and economical changes on Klaipeda county forests (1986-2005). Human Resources - the Main
Factor of Regional Development, 4, Klaipèda University, Faculty of Social Sciences, p. 37-46.

9. Gyventoju skaičiaus pasiskirstymas pagal teritorija, amžiu ir lytį. Lietuvos Respublikos 2011 metu visuotinio gyventoju ir būstu surašymo rezultatai (2013). Vilnius, Statistikos departamentas. 2013 m. sausio 25 d., p. 91 http://osp. stat.gov.lt/documents/10180/217110/Inform_ gyv_sk_pasisk.pdf/cd1f3d45-ef4b-446f-af6af56e23c94519 (žiūrèta 201607 05).

10. Great small towns in France. About-France. com 2010-2016 http://about-france.com/tourism/small-towns.htm (žiūrèta 20160707 ).

11. Kaimo gyvenamosios vietoves. 1989 metu visuotinio gyventoju surašymo duomenys. 1993. Vilnius, Statistikos departamentas. 584-585.

12. Kavaliauskas P. 2011. Kraštovaizdžio samprata ir planavimas: mokomoji knyga. Vilnius: Vilniaus universitetas. www.krast_SMPR PLNV.pdf

13. Klaipedos apskrities kaimo gyvenamosios vietovés ir ju gyventojai. Lietuvos gyventojų ir būsty surašymas 2001. 2003. Vilnius, Statistikos departamentas http://www.osp.stat.gov.lt/documents/10180/212976/Klaipedos_apskritis. pdf/8e90d9ff-408a-4980-b001-a18b7f10e804 (žiūrèta 20160708 ).

14. Kleine und mittlere Städte - Blaupausen der Großstadt? Dokumentation des Experten Kolloquiums am 29. April 2004 in Dortmund, Universität Dortmund. http://www.raumplanung.unidortmund.de/srp/web/dokumente/ downloads/64_SRPapers\%20Nr.1.pdf (žiūrèta $20160708)$.

15. Kriaučiūnas E. 2013. Lietuvos kaimo gyvenviečiu tinklo kaitos ypatumai 1989-2011 metais. http://www.su.lt/bylos/mokslo_leidiniai/ Kaimas/2013_5/kriauciunas.pdf (žiūrèta 20160808 ).

16. Lietuvos Respublikos teritorijos administraciniu vienetu ir ju ribu istatymas, $1994 \mathrm{~m}$. liepos 19 d. Nr. I-558. 1994. 3 straipsnis. https:// www.e-tar.lt/portal/legalAct.html?documentI d=TAR.0120FD7BCFFC (žiūrèta 201701 23).

17. Lietuvos TSR administracinis-teritorinis padalinimas pagal $1949 \mathrm{~m}$. sausio $1 \mathrm{~d}$. padetį. 1949. Vilnius. 134-137.

18. Lietuvos TSR kaimo gyvenamosios vietoves 1959 ir 1970 metais (Visasąunginių gyventoju surašymų duomenys). 1974. Vilnius, Centrinè 
statistikos valdyba prie Lietuvos TSR Ministrų Tarybos. 573-574.

19. Lietuvos TSR kaimo gyvenamosios vietoves (1979 metų Visasąunginio gyventojų surašymo duomenys). 1982. Vilnius, Lietuvos TSR centrinè statistikos valdyba. $574 \mathrm{p}$.

20. Milius J., Ribokas G. 2008. Dirvonai Lietuvos XX ir XXI amžių laukuose. Geografija. 44(1): 9-16.

21. Mūsu Lietuva: krašto vietoviu istoriniai, geografiniai, etnografiniai bruožai. 1968. Parengè B. Kviklys. Vilnius: Lietuvių enciklopedijos l-kla. 1964-1968, 4 t.

22. Pranckietis V., Bogušas V. 2013. Agrarinio kraštovaizdžio kitimo priežastys ir problemos. Urbanistine drieka: miesto ir kaimo sandūra. IV Lietuvos urbanistinis forumas. Kaunas: KTU. 12-19. http://dpakademija.lt/ stor/uploads/2013/07/2010-UF-leidinys.pdf (žiūrèta 201701 17).

23. Purvinas M. 2005. Žemaitijos ir Klaipèdos krašto senųjų kaimų struktūra. Liaudies kultūra. 5(104): 31-39.

24. Ribokas G., Zlatkutė A. 2009. Žemènaudos kaita Anykščių rajono savivaldybejje (Viešintų seniūnijos pavyzdžiu). Annales Geographicae. 42(1-2): 45-54.

25. Selskoje hoziaistvo Litovskoj SSR za 35 let Sovestskoj Vlasti. 1977. Statističeskij sbornik. Vilnius. 32, 313, 395, 397 s. [in Russian].

26. Svirskis A. 2009. Lietuvos kaimas: žvilgsnis $\dot{\imath}$ istorija, dabarti ir ateities vizija. http://www. bernardinai.lt/straipsnis/2009-11-16-antanas-svirskis-lietuvos-kaimas-zvilgsnis-i-istorija-dabarti-ir-ateities-vizija/35411 (žiūrèta $20160705)$.
27. http://www.scb.se/Statistik/MI/MI0811/2010A01/ MI0811_2010A01_SM_MI38SM1203.pdf (žiūrèta 20160705$).$

28. Šilutès rajonas. Tarybu Lietuvos enciklopedija. 1988. Vilnius: Mokslo ir enciklopedijų leidybos institutas. 4 t.: 197-198.

29. Šilutés rajono savivaldybe. https://www.silute.lt/go.php/Geografiniai-ir-demografiniaiduomenys-792859 (žiūrèta 201607 05).

30. Šilutés rajono savivaldybés teritorijos bendrasisplanas. 2010. http://www.2010_T1_1586_ BPL_Silute_aisk1 (žiūrèta 201607 05).

31. Tätorter 2010 Befolkningsstruktur Befolkning; ålder och kön Localities 2010: Population, age and gender, 2012. Sveriges Officiella Statistik. Statistiska Meddelanden MI 38 SM 1201.

32. http://www.scb.se/statistik/MI/MI0810/2010A01C/ MI0810_2010A01C_SM_MI38SM1203.pdf (žiūrèta 201607 05).

33. Urban and Rural Area Definitions for Policy Purposes in England and Wales: Methodology. 2013. V 1.0 https://www.gov.uk/government/ uploads/system/uploads/attachment_ data/file/239477/RUC11 methodology paperaug_28_Aug.pdf (žiūrèta 201607 07).

34. Žemaičių Naumiestis. 1984. Lietuviškoji tarybine enciklopedija. Vilnius: Mokslo ir enciklopedijų leidybos institutas. 12 t. 483 p.

35. Žemaičių Naumiestis. 2015. Visuotine lietuviu enciklopedija. 25 t. Vilnius: Mokslo ir enciklopediju leidybos institutas.

36. Žemés kadastras. 1989. Vilnius: Mokslo leidykla. 728 p. 


\section{Angelija Bučienė, Sébastien Gadal, Jelena Galiniené, Viktoras Gailius}

\section{THE GEOGRAPHIC-RETROSPECTIVE ANALYSIS OF LANDSCAPE IN ŽEMAIČIŲ NAUMIESTIS WARD}

\section{Summary}

Research aim was to analyse semi-natural and agrarian-urban landscape components of Žemaičių Naumiestis ward as well as social-demographic factors and their changes within the ward boundaries and time-scale (from soviet time till recent years) in order to distinguish the common tendencies of these changes. The semi-natural landscape components - forests, water bodies and their area as well as agrarian-urban components (agricultural land use with arable land, pastures and meadows, built-up territories) and their changes in time and space were analysed. Of social-demographic factors, population, density and settlement size were focused on. The statistical and historical document analysis methods as well as distance and GIS modelling were applied. Land cover mapping of the territorial and geographic changes were computed by remote sensing using Landsat series satellite images of the studied area around Žemaičių Naumiestis town $\left(297 \mathrm{~km}^{2}\right)$ in 1988, 1998, 2005 and 2015 and ortographic photo data method in 1997 and 2013.

Žemaičių Naumiestis as a town (the old name is Naumiestis, or Nowe Miasto in Polish) was mentioned in the historical documents from the 17th century. Only in the fourth decade of the 20th century it was named Žemaičiu Naumiestis - as one of the territorial administrative units of western Lithuania. The first collective farm in the ward was founded in 1959, and in the last decade of soviet governance there were two sovhozes specialised in vegetable seed husbandry, milk and meat production, one educational farm, as well as one forestry.

The greatest population and its density in the ward was documented in $1970(4,744$ and 49.2 inhabitants per $\mathrm{km}^{2}$ ), and the greatest population in Žemaičių Naumiestis town in 1985 (2,500). At the same time rural population and its density in the ward decreased. The distinguished spatial changes of rural population decrease were ob- served in the south-eastern part of the ward (decrease by $40-60$ and $>\%$ ), where the number of small villages prevailed. A few of them, like Dekintai, Užšustis and Klebonai, were almost empty.

After restoration of independence in 1990, the land reform changed drastically the configuration of agricultural land plot cover: as a result of restitution of private land, at first the plots of agricultural land decreased in size, but increased in the number of owners, at the same time some plots became abundant, because their owners were too old to manage the farm. Nowadays increase in private farm area is going on. According to the latest Censuses of land in 2003 and 2010, the number of farms in Šilute district and in Žemaičių Naumiestis ward started to decrease, however the total agricultural area even increased. Thus the farms became larger in area.

The research based on different distant methods revealed that in the beginning of the 21 st century there was reduction in agrarian components of landscape and urban (built-up) areas. Semi-natural components (water bodies) have remained unchanged in the area, while the forest area slightly increased. The same tendencies of landscape component plot changes from the end of soviet era up to now have been observed both in the total Žemaičiu Naumietis ward territory as well as in the studied Žemaičiu Naumiestis ward parcel $\left(297 \mathrm{~km}^{2}\right)$. The secondary agricultural land consolidation and stabilisation of agrarian landscape fragmentation is to be documented in the ward nowadays.

Despite different changes in land use, decrease of villages and rural population, the landscape of Žemaičių Naumiestis has remained more agrarian as compared with Silute district, on the average.

The agrarian activities became more diverse, the first ecological farm appeared in 2006, and they have increased in numbers since then. The forests are slightly increasing in the area, thus the situation with natural landscape components in the ward is improving. However, the necessity to strengthen the social-economic-cultural status of population life remains the task of high importance.

Keywords: Žemaičių Naumiestis, landscape components, change analysis, remote sensing, geographic-retrospective point of view 